\title{
IMPACT OF CHEMICAL AND NATURAL WATER SAVING SOIL AMENDMENTS ON GROWTH, YIELD AND WATER USE EFFICIENCY OF "WASHINGTON NAVEL" ORANGE TREES UNDER DEFICIT IRRIGATION CONDITIONS
}

\author{
M.M.S. Abo El-Enien(1) and E.A. Moursi(2) \\ (1) Citrus Research Department, Hort. Res. Instit. ARC. Giza, Egypt. \\ (2) Soils, Water and Environment Research Institute. ARC. Giza, Egypt.
}

Received: May 29, 2019

Accepted: Jul. 22, 2019

ABSTRACT: Due to the limited water resources, it is necessary to study the best ways to reduce the use of irrigation water, increase the efficiency of water use without affecting the growth of trees and maintain the production of citrus productivity under these circumstances. Afield experiment was conducted during 2015 and 2016 seasons at El-Nubaria region, Beheira Governorate to investigate the effect of three irrigation water regimes (100, 75 and $50 \%$ of actual irrigation practiced in the orchard) and soil application of hydrogel (50 and 100g/tree) and organic plant residues (3.5 and $6.5 \mathrm{~kg} / \mathrm{tree}$ ) as chemical and natural water absorbing soil amendments on growth, yield and water use efficiency on "Washington Navel" orange trees grown on a sandy soil under drip irrigation system. The obtained results point out that, applied organic plant residues at rate $6.5 \mathrm{~kg} /$ tree or $100 \mathrm{~g} /$ tree hydrogel under moderate irrigation rate ( $T_{5}$ and $T_{3}$ ) significantly increased the most growth parameters (canopy volume, number of shoots/branch and leaf area), fruit set, leaf relative water content and decrease fruit drop\%. Moderate irrigation rate $+100 \mathrm{~g} /$ tree hydrogel $\left(T_{3}\right)$ and control $\left(T_{1}\right)$ were the best treatments in increasing leaf $N, P, K$ and Ca contents. The highest yield (78.8 and78.47) and (80.36 and $79.06 \mathrm{~kg} / \mathrm{tree})$ was obtained by $T_{3}$ and $T_{5}$ in 2015 and 2016 seasons, respectively. All treatments increased water use efficiency especially $T_{9}$ (5.64 and 5.46 $\mathrm{kg} / \mathrm{m}^{3}$ ) compared with the control which recorded the lowest values (3.16 and $\left.2.93 \mathrm{~kg} / \mathrm{m}^{3}\right)$. Control $\left(T_{1}\right)$ followed by $T_{3}$ and $T_{5}$ tended to improve the physical fruit properties meanwhile $T_{8}$ and $T_{9}$ increased the most of chemical fruit quality. The lowest fruit splitting\% (6.58 and $5.87 \%$ ) coated with $T_{3}$ and $T_{5}$. Soil microorganisms content and dehydrogenase activity were increased under moderate irrigation rate +3.5 or 6.5 organic plant residues ( $T_{4}$ and $\left.T_{5}\right)$ compared to the control $\left(T_{1}\right)$.

Key words: Water absorbing soil amendments, Citrus trees, growth, yield and fruit splitting.

\section{INTRODUCTION}

Citrus is the most important fruit crops in Egypt, which occupies the first position among fruit crops, with more than 3237157 fed. and an average annual production of about 3438030 tons (FAO, 2016). "Washington Navel" orange is one of the most common cultivars and has one of the best fruit exportation in Egypt. In arid and semiarid regions, drought stress is the main factor limiting crop growth and productivity (Todorov et al., 1998). Efficient management of soil moisture is critical for agricultural production in areas with scarce water resources (Eneji et al., 2013).

Under climate change conditions and limitation of water resources which faces Egypt, we should do our best towards effective renationalization of irrigation water on the orchards level. 
In Egypt, water is one of the most critical factors in crop production. Rainfall is low, So, most of agricultural production is mostly dependent upon irrigation. Water resources are limited and concentrated upon the Nile River.

Minimizing water losses can be applied using soil amendments, which improve the soil physical properties and increase water irrigation efficiency as well as rationalization of irrigation water (Ezzat et al., 2011). One of the newest soil amendments used in this respect is the use of water saving amendments i.e. hydrogel polymers for enhancing water and nutrient use efficiency which become more vital over time, particularly in arid and semiarid regions with limiting water sources, hydrogel is a superabsorbent polymer which absorbs water hundreds of times of its own dry weight. Soil water and nutrients stored in hydrogel are released gradually for plant growth under water limiting conditions (Yazdani et al., 2007). Hydrogel is occasionally referred to "Root watering crystals" or "water retention granules" because it swells like sponges to be as several times of its original size, when it contacts with a water, therefore increases soil water holding capacity and decreases irrigation frequency (Jamnicka et al., 2013). Hydrogel can which it can absorb water until $400 \%$ over its dry weight so decrease drought stress and improve the vegetative growth parameters (Khoshnevis, 2003), it can increase the efficiency of coefficient agriculture water and decrease cost and irrigation quantity (Tongo et al., 2014). Plant residues (organic residues) is an important biological resource so the return it to the field is a valuable cultural practice to increase both soil water- holding capacity and providing nutrients and organic matters as well as improving soil physical properties (Lou et al., 2011). So, improved water productivity (WP) using different strategies, is a key concept to solve the water scarcity. Hence today, efforts are being focused on developing not only alternative irrigation methods but also new water management methods in order to reduce water amounts with maintaining maximum tree growth, without significantly affecting fruits yield.

The objective of this study was to investigate the impact of some water saving substances on growth, yield, fruit quality and water use efficiency of "Washington Navel" orange trees under deficit irrigation conditions.

\section{MATERIALS AND METHODS}

The present study was carried out during 2015 and 2016 seasons on 10 years old "Washington Navel" orange trees (Citrus sinensis (L.) Osbeck) budded on Volkamer lemon (Citrus volkameriana L.), spaced at $4 \times 6$ meters (175 trees/fed.) grown on a sandy soil under drip irrigation system at El-Nubaria region, Beheira Governorate, Egypt. The trees subjected to cultural practices usually done in this area.

The soil orchard is classified as sandy soil. Some chemical, physical properties and moisture content of soil experimental site are presented in Tables 1 and 2 .

Table (1): Some chemical and physical properties of the experimental soil.

\begin{tabular}{|c|c|c|c|c|c|c|c|c|c|c|}
\hline \multirow[t]{2}{*}{ Characters } & \multicolumn{3}{|c|}{$\begin{array}{c}\text { Particle size } \\
\text { distribution (\%) }\end{array}$} & \multirow[t]{2}{*}{$\begin{array}{l}\text { Textural } \\
\text { class }\end{array}$} & \multirow[t]{2}{*}{$\mathrm{PH}$} & \multirow[t]{2}{*}{$\begin{array}{c}E c \\
\left(\mathrm{dSm}^{-1}\right)\end{array}$} & \multirow[t]{2}{*}{$\begin{array}{l}\text { O.M } \\
(\%)\end{array}$} & \multicolumn{3}{|c|}{ Available (ppm) } \\
\hline & Sand & Silt & Clay & & & & & $\mathbf{N}$ & $\mathbf{P}$ & $\mathbf{K}$ \\
\hline Value & 88.57 & 4.73 & 6.70 & Sandy & 8.20 & 1.47 & 0.10 & 17.1 & 5.2 & 58.47 \\
\hline
\end{tabular}


Impact of chemical and natural water saving soil amendments on growth, ..........

Table (2): Soil moisture constant for the experimental site.

\begin{tabular}{|c|c|c|c|c|}
\hline $\begin{array}{c}\text { Soil depth } \\
(\mathrm{cm})\end{array}$ & $\begin{array}{c}\text { Field capacity } \\
(\%)\end{array}$ & Wilting point (\%) & $\begin{array}{c}\text { Available water } \\
(\%)\end{array}$ & $\begin{array}{c}\text { Bulk } \\
\text { density }\left(\mathbf{g} / \mathbf{c m}^{3}\right)\end{array}$ \\
\hline $0-30$ & 12.32 & 4.25 & 8.07 & 1.65 \\
$30-60$ & 12.10 & 4.21 & 7.89 & 1.66 \\
$60-90$ & 11.80 & 4.19 & 7.61 & 1.68 \\
\hline Average & 12.07 & 4.22 & 7.85 & 1.66 \\
\hline
\end{tabular}

Eighty one trees were selected as uniform as possible in size and load, and arranged in a randomized complete block design, each treatment replicated three times with three trees for each replicate. The experiment included 9 treatments as follow:

$\mathrm{T}_{1}$ - Control (Actual irrigation practiced in the orchard):

$\mathrm{T}_{2}$ - Moderate irrigation treatment $\mathbf{( 7 5 \%}$ from the control) + Hydrogel polymer at rate $50 \mathrm{~g} /$ tree.

$T_{3-}$ Moderate irrigation treatment + Hydrogel polymer at rate $100 \mathrm{~g} /$ tree.

$\mathrm{T}_{4-}$ Moderate irrigation treatment + organic plant residues at rate 3.5 $\mathrm{kg} / \mathrm{tree}$.

$\mathrm{T}_{5-}$ Moderate irrigation treatment + organic plant residues at rate 6.5 $\mathrm{kg} /$ tree.

T6- Deficit irrigation treatment $\mathbf{5 0} \%$ from the control) + Hydrogel polymer at rate $50 \mathrm{~g} /$ tree.

T7- Deficit irrigation treatment + Hydrogel polymer at rate $100 \mathrm{~g} /$ tree.

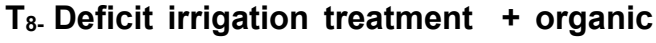
plant residues at rate $3.5 \mathrm{~kg} / \mathrm{tree}$.

$\mathrm{T}_{9}$ - Deficit irrigation treatment) + organic plant residues at rate $6.5 \mathrm{~kg} / \mathrm{tree}$.

The irrigation levels $100 \%$ as control, moderate and deficit irrigation (75 and $50 \%$ of the control) were controlled by using 16, 12, 8 emitters/tree (4L/hr), respectively at two lateral JR line for each row of the trees with emitters each $50 \mathrm{~cm}$. The amount of irrigation was calculated as follow: The amount of irrigation water $=$ number of drippers $x$ discharge of irrigation water (L/hr) $x$ operating time.
The quantity of irrigation water applied in the different irrigation treatments during each growing season were showed in Table (3).

Hydrogel polymer known "Barbary Plant G3" (40\% Hydro polymer, $6.5 \% \mathrm{~N}$, $4.8 \% \mathrm{P}, 8.2 \% \mathrm{~K}$ and hold capacity at 300 $500 \%$ ) produced by Lucky Star TG., Egypt and organic plant residues named "HUNDZsoil ${ }^{\circledR}$ " is a natural soil conditioner that is made out of $100 \%$ cellulose, shaped in grains, and varies in size 0.2 into $2 \mathrm{~mm}(78.16 \%$ organic matter, $1.28 \% \mathrm{~N}, 0.07 \% \mathrm{P}, 0.11 \% \mathrm{~K}$ and hold capacity at $278-300 \%$ ) were obtained from Hundz soil Company., Egypt., were added once at last week of January in two trenches $(100 \mathrm{~cm}$ length $\times 50 \mathrm{~cm}$ width $x$ $50 \mathrm{~cm}$ depth) on both sides of the tree in both seasons.

The following data was recorded: 1- Vegetative growth parameters:

Four main branches, in different direction on each tree were labeled. All current shoots developed on these branches in spring were used for measuring growth parameters i.e. average number of shoots, shoot length and number of leaves. Also, canopy volume of tree was calculated at the beginning and the end of experimental according to the following equation: $\mathrm{CV}=$ $0.528 \times \mathrm{H} \times \mathrm{D} 2$. Whereas, $\mathrm{H}=$ tree height, $D=$ tree diameter (Castle, 1983) then increment of canopy volume was calculated, leaf area $\left(\mathrm{cm}^{2}\right)$ was estimated using formula: Leaf area $=2 / 3 \times$ length $x$ width (Chou, 1966). 
Table (3): The quantity of irrigation water applied ( $\mathrm{m}^{3} / \mathrm{fed}$.) in the different irrigation treatments during 2015 and 2016 seasons.

\begin{tabular}{|l|c|c|c|c|c|c|}
\hline \multicolumn{1}{|c|}{ Treatment } & \multicolumn{2}{|c|}{ Control (100\%) } & \multicolumn{2}{c|}{$\begin{array}{c}\text { Moderate } \\
(75 \% \text { of control })\end{array}$} & \multicolumn{2}{c|}{$\begin{array}{c}\text { Deficit } \\
(50 \% \text { of control) }\end{array}$} \\
\cline { 2 - 7 } & 2015 & 2016 & 2015 & 2016 & 2015 & 2016 \\
\hline $\begin{array}{l}\text { Total irrigation water } \\
\text { (l/tree/year) }\end{array}$ & 22235 & 24060 & 16676.25 & 18045 & 11117.5 & 12030 \\
\hline $\begin{array}{l}\text { Total irrigation water } \\
\left(\mathrm{m}^{3} / \text { fed/year) }\right.\end{array}$ & 3891.125 & 4210.5 & 2918.34 & 3157.87 & 1945.56 & 2105.25 \\
\hline
\end{tabular}

\section{2- Leaf mineral content:}

At the end of September from nonfruiting spring flush shoots 40 mature leaves/ tree were sampled in both seasons, washed, dried at $70^{\circ} \mathrm{C}$ to constant weight ground and digested for determination leaf mineral content. Nitrogen were determined by Microkjeldahl method as outlined by Chapman and Pratt (1978). Phosphorus was determined using spectrophotometer according to Murphy and Riely (1962). Potassium determined by flame photometer according to Jackson (1967).

\section{3- Relative water content (RWC):}

Was determined according to Morgan (1984) as follow:

RWC $\%=$

(leaf fresh weight(g) - leaf dry weight $(g)) \times 100$

(turgid weight - leaf dry weight)

\section{4- Fruit set and drop\%}

Initial and final fruit set\% calculated by the following equations: Initial fruit set $\%=$ (No. of fruitlettes $I$ Total No. of flowers) $\times 100$. Meanwhile, final fruit set $\%=$ (No. of fruits at end of June $/$ Total No. of flowers) $\times 100$. also, The percentage of June drop was calculated according the equations: June drop \% = (No. of fruitlettes- No. of fruits at end of June / No. of fruitlettes) $\times 100$
5- Yield and Water use efficiency (WUE):

At harvest time (December $15^{\text {th }}$ in both seasons), number of fruit and $\mathrm{kg} / \mathrm{tree}$, yield as $\mathrm{kg} / \mathrm{tree}$ as well as ton/fed. were calculated. Water use efficiency (WUE) was calculated according to Ali et al., (2007) as follow: WUE $=$ yield(kg/fed.) $/$ water applied $\left(\mathrm{m}^{3} / \mathrm{fed}\right.$.)

\section{6- Fruit quality:}

A sample of 10 healthy fruits were taken at random from each tree at harvest time $\left(15^{\text {th }}\right.$ December $)$ and prepared for determination physical and chemical fruit properties according to (A.O.A.C., 1995). i.e. fruit weight (g), fruit height, diameter $(\mathrm{cm})$, peel thickness $(\mathrm{mm})$ and fruit juice \%., Total soluble solids (TSS \%) was determined by using hand refractmeter, total acidity was determined as citric acid, ascorbic acid as $\mathrm{mg} / 100 \mathrm{ml} / \mathrm{juice}$ and TSS/acid ratio was calculated. The number of splitting fruits was counted at weekly intervals from $15^{\text {th }}$ July till the time of harvesting and the percentage of splitting fruits was calculated as: No. of splitted fruits / Total No. of harvested fruits $\times 100$.

\section{7- Soil properties}

Microorganisms were calculated as number of colonies/gram soil according to Saleh (2002) and dehydrogenase 
activity (mg $\mathrm{g}^{-1}$ dry soil/96h) was estimated according to Tabatabai (1982).

Data were analyzed by MSTATC computer software program (Bricker, 1991). The obtained data were subjected to analysis of variance according Snedecor and Cochran (1990). Duncan's multiple range test (Duncan, 1955) at $5 \%$ level was used to compare the means.

\section{RESULTS AND DISCUSSION}

1- Vegetative growth parameters:

Results in Table (4) and Fig. (1) revealed that moderate irrigation rate+ $6.5 \mathrm{~kg} /$ tree organic plant residues $\left(T_{5}\right)$ followed by $\left(T_{3}\right)$ significantly increased canopy volume and increment of canopy volume compared with the other treatments except for the control in the first season, while the lowest values obtained with $T_{6}$ in both seasons. Regarding to number of shoots/branch and leaf area, there was no significant differences observed among treatments in the first season, while in the second one the differences were significantly, however, moderate irrigation rate + $100 \mathrm{~g} /$ tree hydrogel $\left(\mathrm{T}_{3}\right)$ and $6.5 \mathrm{~kg} /$ tree organic plant residues $\left(T_{5}\right)$ gave the highest values in this respect meanwhile, the lowest number obtained with $T_{6}$. The other treatments gave intermediate values. The highest number of leaves/shoot, resulted by treatment of moderate irrigation rate $+100 \mathrm{~g} /$ tree hydrogel $\left(T_{3}\right)$ compared with the lowest number obtained by $\left(T_{6}\right)$ in the first season. But in the second one all treatments increased the number of leaves without significant differences among them except of $T_{8}$ and $T_{9}$ which recorded the lowest number.

The increment in vegetative growth parameters due to organic plant residues and hydrogel may be due to increase in organic materials and availability of proper amounts of nutrients in the soil, on the other hand, improvement of water holding capacity and physical properties of the soil, better absorption of irrigation water and its storage in the soil and so, prevent the moisture stresses which reflected on vegetative growth (Sheikh et al., 2010).In addition, Andry et al., (2009) confirmed the effects of superabsorbent polymers in density and growth of the root due to improvement in physical condition of the soil. This growth increase is caused by indirect role of amendment materials increase $N, P$ and $k$ uptake by the plant, appropriate aeration and available water by increasing the water holding capacity of the soil which reduce water stress of plants resulting in increased growth and plant performance. However, Moldes et al., (2007) who stated that applying compost enhanced the root uptake activity of such nutrients as $\mathrm{N}, \mathrm{P}, \mathrm{K}, \mathrm{Ca}$ and $\mathrm{Mg}$. The root vigor reflects the growth performance of plants and the nutrient absorptive capacity of the roots. Barki et al., (2018) found that treatments of superabsorbent and organic wastes enhancement the growth parameters of olive trees,. In the same line, Fagundes et al., (2014) and Pattanaaik et al., (2015) on citrus trees.

\section{2- Leaf mineral content}

Results in Table (5) showed that irrigated Washington Navel trees with actual irrigation practiced in orchard $\left(\mathrm{T}_{1}\right)$ and moderate irrigation treatment + $100 \mathrm{~g} /$ tree Hydrogel polymer $\left(\mathrm{T}_{3}\right)$ or 6.5 $\mathrm{kg} /$ tree organic plant residues $\left(T_{5}\right)$ had statistically the richest leaves in $\mathbf{N}$ content in the first season without significant differences among them, while in the second one $\left(T_{3}\right)$ increased leaf $\mathbf{N}$ content compared with the other treatments, the reverse was true with ( $T_{4}$ and $\left.T_{8}\right)$. The control ( $\left.T_{1}\right)$ gave the highest $P$ content in leaves $(0.27$ and $0.28 \%)$ compared to the lowest values (0.20 and $0.20 \%$ ) which recorded by $\mathrm{T}_{8}$ in both seasons, respectively. 


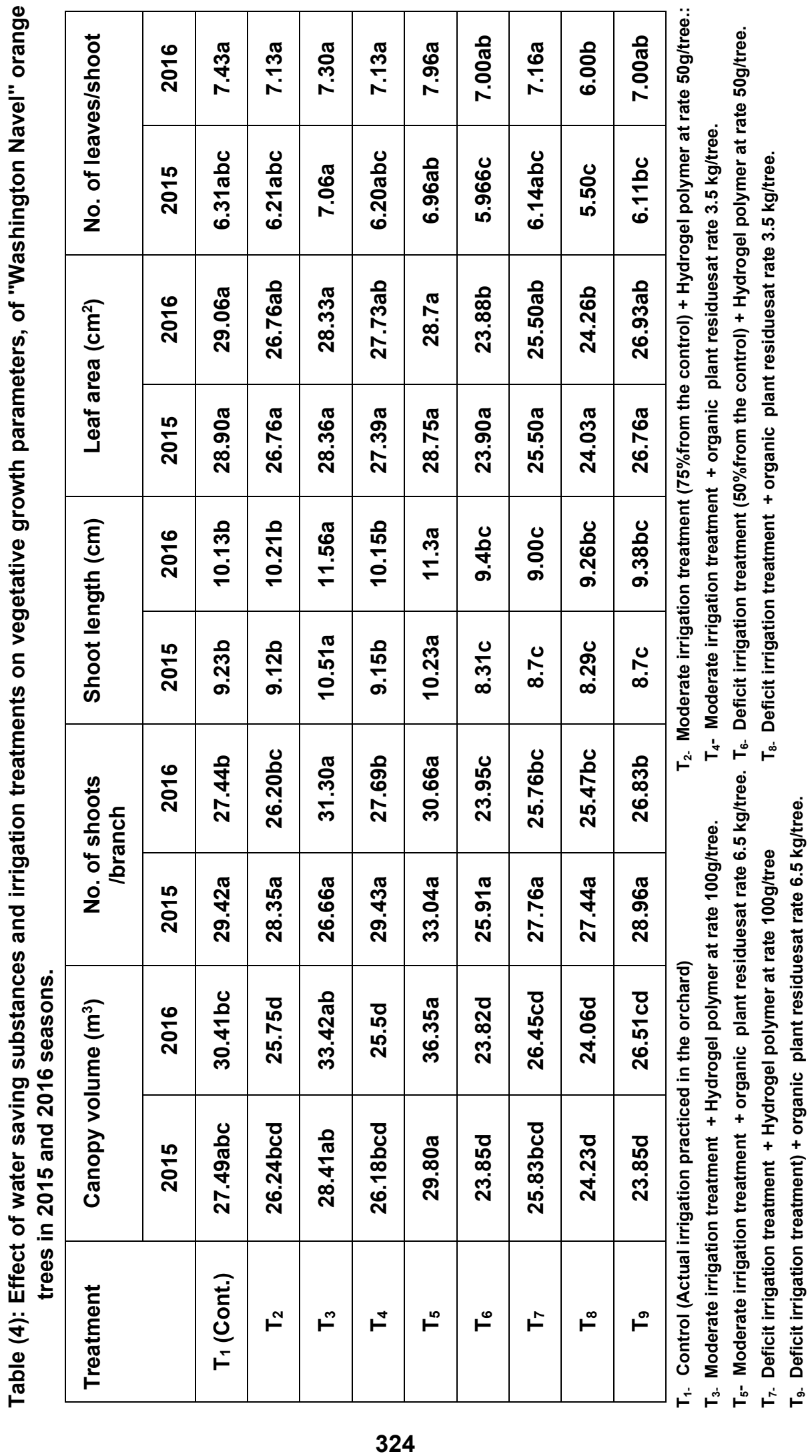




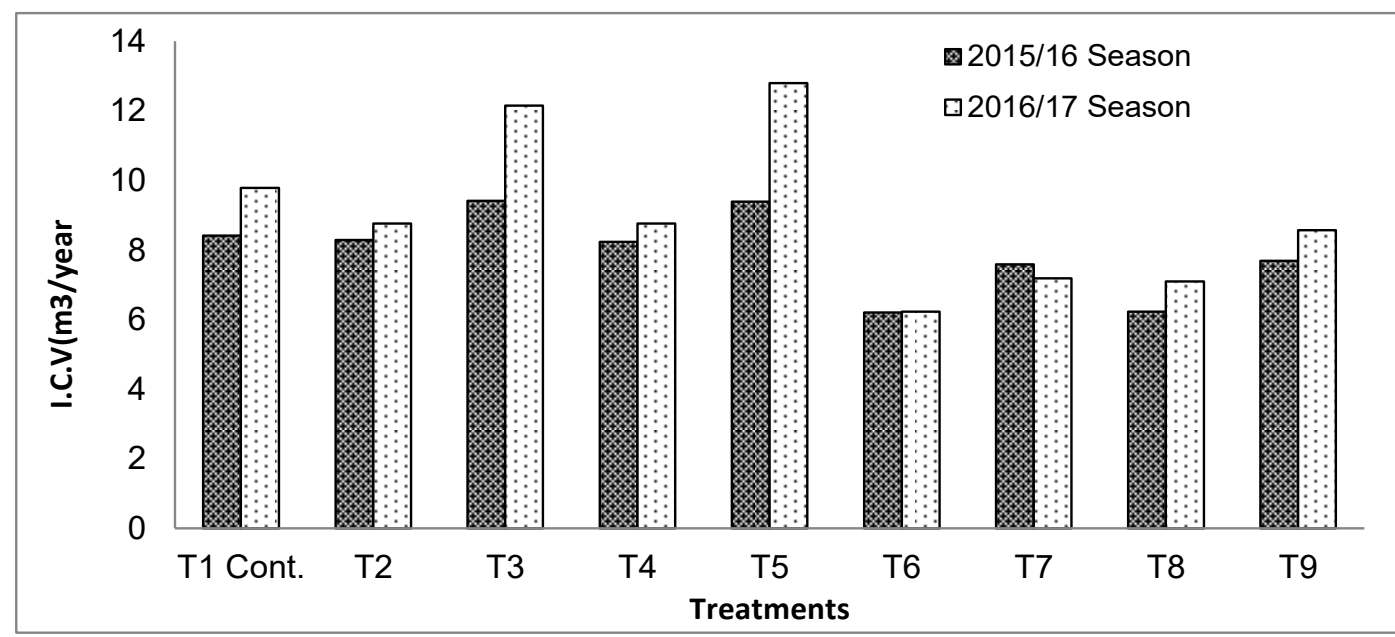

Fig. (1): Increment in canopy volume ( $\mathrm{m}^{3} / \mathrm{year}$ ) of "Washington Navel" orange trees as affected by some water saving substances and irrigation treatments in 2015 and 2016 seasons.

Table (5): Effect of some water saving substances and irrigation treatments on leaf mineral contents of "Washington Navel" orange trees in 2015 and 2016 seasons.

\begin{tabular}{|c|c|c|c|c|c|c|c|c|}
\hline \multirow{2}{*}{ Treatment } & \multicolumn{2}{|c|}{$\mathrm{N} \%$} & \multicolumn{2}{c|}{$\mathrm{P} \%$} & \multicolumn{2}{c|}{ K\% } & \multicolumn{2}{c|}{ Ca \% } \\
\cline { 2 - 9 } & 2015 & 2016 & 2015 & 2016 & 2015 & 2016 & 2015 & 2016 \\
\hline $\mathrm{T}_{1}$ (Cont.) & $2.63 \mathrm{a}$ & $2.51 \mathrm{ab}$ & $0.27 \mathrm{a}$ & $0.28 \mathrm{a}$ & $1.52 \mathrm{bc}$ & $1.52 \mathrm{~b}$ & $2.93 \mathrm{~b}$ & $2.90 \mathrm{ab}$ \\
\hline $\mathrm{T}_{2}$ & $2.54 \mathrm{ab}$ & $2.66 \mathrm{a}$ & $0.25 \mathrm{bc}$ & $0.25 \mathrm{abc}$ & $1.48 \mathrm{c}$ & $1.48 \mathrm{~b}$ & $2.96 \mathrm{~b}$ & $2.97 \mathrm{a}$ \\
\hline $\mathrm{T}_{3}$ & $2.67 \mathrm{a}$ & $2.47 \mathrm{~b}$ & $0.26 \mathrm{ab}$ & $0.23 \mathrm{ab}$ & $1.60 \mathrm{a}$ & $1.61 \mathrm{a}$ & $3.26 \mathrm{a}$ & $3.18 \mathrm{a}$ \\
\hline $\mathrm{T}_{4}$ & $2.45 \mathrm{~b}$ & $2.63 \mathrm{ab}$ & $0.24 \mathrm{c}$ & $0.25 \mathrm{abc}$ & $1.50 \mathrm{c}$ & $1.49 \mathrm{~b}$ & $2.91 \mathrm{~b}$ & $2.93 \mathrm{a}$ \\
\hline $\mathrm{T}_{5}$ & $2.63 \mathrm{a}$ & $2.50 \mathrm{ab}$ & $0.26 \mathrm{ab}$ & $0.26 \mathrm{ab}$ & $1.59 \mathrm{ab}$ & $1.60 \mathrm{a}$ & $3.11 \mathrm{ab}$ & $3.06 \mathrm{a}$ \\
\hline $\mathrm{T}_{6}$ & $2.46 \mathrm{~b}$ & $2.53 \mathrm{ab}$ & $0.21 \mathrm{e}$ & $0.22 \mathrm{~cd}$ & $1.45 \mathrm{c}$ & $1.46 \mathrm{~b}$ & $2.30 \mathrm{~cd}$ & $2.22 \mathrm{~b}$ \\
\hline $\mathrm{T}_{7}$ & $2.54 \mathrm{ab}$ & $2.46 \mathrm{~b}$ & $0.23 \mathrm{~d}$ & $0.23 \mathrm{bcd}$ & $1.49 \mathrm{c}$ & $1.50 \mathrm{~b}$ & $2.51 \mathrm{c}$ & $2.33 \mathrm{~b}$ \\
\hline $\mathrm{T}_{8}$ & $2.45 \mathrm{~b}$ & $2.53 \mathrm{ab}$ & $0.20 \mathrm{e}$ & $0.20 \mathrm{~d}$ & $1.46 \mathrm{c}$ & $1.46 \mathrm{~b}$ & $2.17 \mathrm{~d}$ & $2.15 \mathrm{~b}$ \\
\hline $\mathrm{T}_{9}$ & $2.53 \mathrm{ab}$ & $2.63 \mathrm{ab}$ & $0.24 \mathrm{c}$ & $0.24 \mathrm{bc}$ & $1.50 \mathrm{c}$ & $1.50 \mathrm{~b}$ & $2.53 \mathrm{c}$ & $2.39 \mathrm{~b}$ \\
\hline
\end{tabular}

$T_{1}$. Control (Actual irrigation practiced in the orchard)

$\mathrm{T}_{2}$. Moderate irrigation treatment $(75 \%$ from the control) + Hydrogel polymer at rate $50 \mathrm{~g} /$ tree.:

$\mathrm{T}_{3}$. Moderate irrigation treatment + Hydrogel polymer at rate $100 \mathrm{~g} /$ tree.

$\mathrm{T}_{4}$ - Moderate irrigation treatment + organic plant residuesat rate $3.5 \mathrm{~kg} / \mathrm{tree}$.

$\mathrm{T}_{5}$ - Moderate irrigation treatment + organic plant residuesat rate $6.5 \mathrm{~kg} / \mathrm{tree}$.

$\mathrm{T}_{6}$. Deficit irrigation treatment $(50 \%$ from the control) + Hydrogel polymer at rate $50 \mathrm{~g} /$ tree.

$\mathrm{T}_{7 .}$. Deficit irrigation treatment + Hydrogel polymer at rate $100 \mathrm{~g} /$ tree

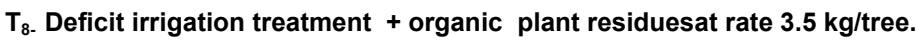

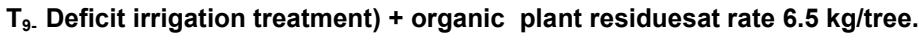


Add the hydrogel polymer at rate $100 \mathrm{~g} /$ tree $\left(T_{3}\right)$ under moderate irrigation was the best treatment in increasing leaf $K$ content ( 1.60 and $1.61 \%$ ) followed by $T_{5}$ (1.59 and $1.60 \%)$ compared with the control.

The highest leaf $\mathrm{Ca}$ content obtained by $T_{3}$ in the first season, meanwhile, in the second one $\left(T_{2}, T_{3}, T_{4}\right.$ and $\left.T_{5}\right)$ increased $\mathrm{Ca}$ content without significant differences among them compared to various treatments. According to the previous results, it could be concluded that application of hydrogel and organic west compost enhances leaf mineral contents because hydrogel enables absorbing and retaining considerable amount of water and nutrients that would be slowly released into tree roots. This may be due to increase in the nutrient use efficiency of soil treated with treatments and improving in physiochemical conditions of soil and affecting the trees response to mitigate drought (Buchholz and Graham, 1998). These results are in harmony with those reported by Vichiato et al., (2004) on citrus trees, Abd El-Rhman and Mohamed (2017) on Egazy olive trees.

\section{3-Relative water content (RWC)}

Results illustrated in Fig. (2) quite evident that $\mathrm{T}_{3}($ Average $=81.23 \%), \mathrm{T}_{1}$ $($ Average $=81.08 \%)$ and $T_{5}($ Average $=$ $80.0 \%$ ) significantly exceeds RWC when compared to the lowest values obtained by T8 (Average $=64.94 \%$ ) and $\mathrm{T}_{9}$ (Average $=67.48 \%$ ). Other treatments gave intermediate values. Improving relative water content under water saving substances treatments may be due to maintain enough available water for trees to overcome drought stress injuries. In this line, Fernando et al., (2013) who found that, hydrogel amendment significantly increased the plant available water (PAW) in sand soil compared to the control. Also, Arbona et al., (2015) on citrus trees and Barki et al., (2018) on olive trees who found that, hydrogel treatment enhance the capacity to avoid drought damages of trees and improve leaf relative water content

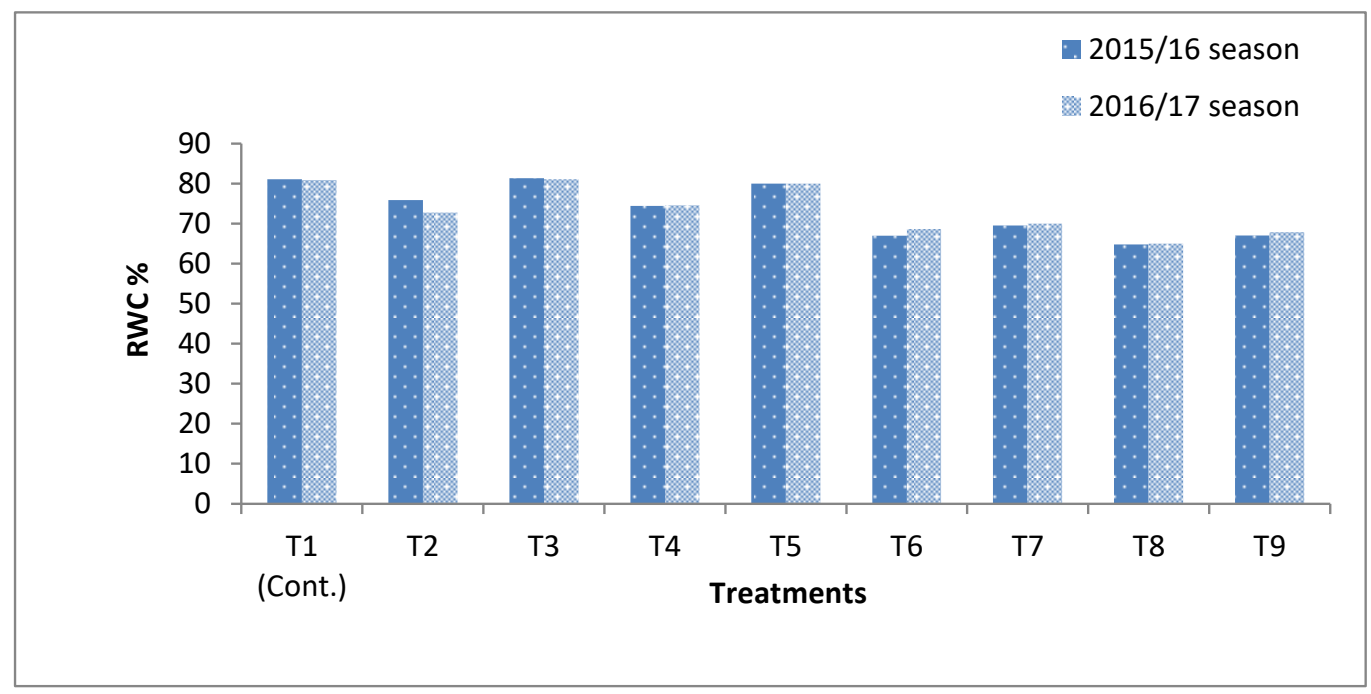

Fig. (2): Effect of some water saving substances and irrigation treatments on leaf relative water content (RWC) of "Washington Navel" orange tree in 2015 and 2016 seasons. 
4-Fruit set and drop\%:

Results in Table (6) showed that the initial fruit set $\%$ was significantly higher when the trees treated with $100 \mathrm{~g}$ hydrogel /tree $\left(T_{3}\right)$ or $6.5 \mathrm{~kg} /$ tree organic plant residues $\left(T_{5}\right)$ under moderate irrigation rate followed by $\left(\mathrm{T}_{4}\right)$ compared to the control and other treatments while, the lowest values obtained by $\left(T_{8}\right.$ and $\left.T_{9}\right)$. The maximum percentage of final fruit set were observed with treatments of $\mathrm{T}_{2}(2.23$ and $2.43 \%), \mathrm{T}_{3}(2.34$ and $2.34 \%)$ and $\mathrm{T}_{5}$ (2.38 and $2.34 \%$ ) on the other hand the lowest values obtained by the control $(1.28$ and $1.70 \%)$ in both seasons. The lowest percentage of fruit drop resulted by $T_{3}(5.44$ and $5.61 \%)$ and $T_{5}$ (5.60 and $5.70 \%$ ) compared to $\mathrm{T}_{8}$ (deficit irrigation rate $+3.5 \mathrm{~kg} /$ tree organic plant residues) which recorded the highest values $(9.71 \%)$, while the highest values in the second season recorded with $\mathrm{T}_{1}(9.60 \%)$, $\mathrm{T}_{2}(8.73 \%), \mathrm{T}_{4}(9.11 \%), \mathrm{T}_{6}(7.3), \mathrm{T}_{8}(9.47 \%)$. This results may be due to the fact that the soil was wet for a longer time increasing the microbial activity as well as increasing fruit set and reducing the fruit drop due to water deficit (Pattanaaik et al., 2015). The same results was obtained by El-Zawily (2016), Zaghloul and Moursi (2017) on "Navel" orange trees who declared that, decreasing or increasing soil moisture content may subject roots to inefficient water which caused the increase of fruit drop \% especially during June drop period, so to avoid that stress, soil must be kept fairly wet during summer months.

Table (6): Effect of some water saving substances and irrigation treatments on fruit set and drop percentage of "Washington Navel" orange trees in 2015 and 2016 seasons.

\begin{tabular}{|c|c|c|c|c|c|c|}
\hline \multirow{2}{*}{ Treatment } & \multicolumn{2}{|c|}{$\begin{array}{c}\text { Initial fruit set } \\
\text { (\%) }\end{array}$} & \multicolumn{2}{c|}{$\begin{array}{c}\text { Final fruit set } \\
\text { (\%) }\end{array}$} & \multicolumn{2}{c|}{$\begin{array}{c}\text { June drop } \\
\text { (\%) }\end{array}$} \\
\cline { 2 - 7 } & 2015 & 2016 & 2015 & 2016 & 2015 & 2016 \\
\hline $\mathrm{T}_{1}$ (Cont.) & $9.49 \mathrm{~cd}$ & $9.25 \mathrm{bcd}$ & $1.28 \mathrm{~b}$ & $1.70 \mathrm{a}$ & $9.4 \mathrm{ab}$ & $9.60 \mathrm{a}$ \\
\hline $\mathrm{T}_{2}$ & $10.01 \mathrm{bc}$ & $10.00 \mathrm{~b}$ & $2.23 \mathrm{a}$ & $2.43 \mathrm{a}$ & $8.81 \mathrm{ab}$ & $8.73 \mathrm{a}$ \\
\hline $\mathrm{T}_{3}$ & $11.20 \mathrm{a}$ & $11.14 \mathrm{a}$ & $2.43 \mathrm{a}$ & $2.43 \mathrm{a}$ & $5.44 \mathrm{~d}$ & $5.60 \mathrm{c}$ \\
\hline $\mathrm{T}_{4}$ & $10.22 \mathrm{~b}$ & $9.78 \mathrm{bc}$ & $2.05 \mathrm{ab}$ & $2.2 \mathrm{a}$ & $9.07 \mathrm{ab}$ & $9.11 \mathrm{a}$ \\
\hline $\mathrm{T}_{5}$ & $11.31 \mathrm{a}$ & $11.18 \mathrm{a}$ & $2.38 \mathrm{a}$ & $2.43 \mathrm{a}$ & $5.61 \mathrm{~d}$ & $5.70 \mathrm{c}$ \\
\hline $\mathrm{T}_{6}$ & $8.03 \mathrm{f}$ & $8.46 \mathrm{de}$ & $1.73 \mathrm{ab}$ & $1.73 \mathrm{a}$ & $8.37 \mathrm{ab}$ & $8.75 \mathrm{a}$ \\
\hline $\mathrm{T}_{7}$ & $8.95 \mathrm{de}$ & $9.0 \mathrm{cde}$ & $1.84 \mathrm{ab}$ & $1.82 \mathrm{a}$ & $6.8 \mathrm{~cd}$ & $6.73 \mathrm{~b}$ \\
\hline $\mathrm{T}_{8}$ & $8.08 \mathrm{f}$ & $8.16 \mathrm{e}$ & $1.91 \mathrm{ab}$ & $1.90 \mathrm{a}$ & $9.71 \mathrm{a}$ & $9.47 \mathrm{a}$ \\
\hline $\mathrm{T}_{9}$ & $8.78 \mathrm{e}$ & $8.39 \mathrm{de}$ & $1.90 \mathrm{ab}$ & $1.89 \mathrm{a}$ & $8.02 \mathrm{bc}$ & $9.17 \mathrm{a}$ \\
\hline
\end{tabular}

T1. Control (Actual irrigation practiced in the orchard)

$\mathrm{T}_{2}$ - Moderate irrigation treatment (75\%from the control) + Hydrogel polymer at rate $50 \mathrm{~g} /$ tree.:

$\mathrm{T}_{3}$ - Moderate irrigation treatment + Hydrogel polymer at rate $100 \mathrm{~g} /$ tree.

$\mathrm{T}_{4}$ - Moderate irrigation treatment + organic plant residuesat rate $3.5 \mathrm{~kg} /$ tree.

$\mathrm{T}_{5}$ - Moderate irrigation treatment + organic plant residuesat rate $6.5 \mathrm{~kg} /$ tree.

$\mathrm{T}_{6}$ - Deficit irrigation treatment $(50 \%$ from the control) + Hydrogel polymer at rate $50 \mathrm{~g} /$ tree.

$\mathrm{T}_{7}$. Deficit irrigation treatment $+\mathrm{Hydrogel}$ polymer at rate $100 \mathrm{~g} /$ tree

T8- Deficit irrigation treatment + organic plant residuesat rate $3.5 \mathrm{~kg} /$ tree.

$\mathrm{T}_{9}$. Deficit irrigation treatment) + organic plant residuesat rate $6.5 \mathrm{~kg} /$ tree. 


\section{5-Yield and water use efficiency $\left(\mathrm{kg} / \mathrm{m}^{3}\right)$ :}

Results in Table (7) showed that the highest number of fruit/tree was recorded by $T_{3}$ (311.3 and 295.5) and $T_{5}$ (304.96 and 297fruit/tree) However, the highest yield as $\mathrm{kg} /$ tree was obtained also by $\mathrm{T}_{3}$ (78.8 and $78.47 \mathrm{~kg} /$ tree) and $\mathrm{T}_{5}$ ( 80.3 and $79.06 \mathrm{~kg} /$ tree) followed by $\mathrm{T}_{1} \quad(70.28$ and $70.51 \mathrm{~kg} /$ tree) compared with the other treatments in both seasons, respectively. Concerning yield as ton/fed, results showed the same trend as that observed for yield as $\mathrm{kg} /$ tree. Hydrogel and organic west compost has no direct nutritional roles in increasing the yield of the plants is due to improvement physical condition of the soil and increasing plant mineral uptake (Panayiotis et al., (2004) which increase the growth as shown in Tables (4 and 5) which reflected on productivity of trees. these results are finding with those of Pattanaaik et al., (2015) on Khasi mandarin.

Water use efficiency $\left(\mathrm{kg} / \mathrm{m}^{3}\right)$ :

Results illustrated in Fig. (3) showed that all treatments increased water use efficiency compared with the control $\left(\mathrm{T}_{1}\right)$. The highest values of WUE were obtained with $\mathrm{T}_{6}\left(5.52\right.$ and $\left.5.17 \mathrm{~kg} / \mathrm{m}^{3}\right), \mathrm{T}_{7}(5.8$ and 5.38), $\mathrm{T}_{8}$ (5.46 and 5.04) and $\mathrm{T}_{9}(5.64$ and $5.46 \mathrm{~kg} / \mathrm{m}^{3}$ ) compared with the lowest values $\left(3.16\right.$ and $\left.2.93 \mathrm{~kg} / \mathrm{m}^{3}\right)$ which recorded with the control $\left(\mathrm{T}_{1}\right)$ in both seasons, respectively. Addition of organic waste compost or hydrogels in soils can positively affect water use efficiency his may be due to modify the soil structure by stabilizing aggregates (Lentz et al., 1992), increasing the water holding capacity, reducing deep percolation and rising evaporation losses in sandy soils. Moreover, the use of polymers leads to improved water use efficiency since the water that would have then leached beyond the root zone is captured (El-Shafei et al., 1992). A similar observation has been reported by Uckoo et al., (2009) on citrus trees showed that the application of organic plant residues under low water use system increased soil moisture which reflected to increase water use efficiency, also, Chehab et al., (2017) on olive trees who concluded that the application of hydrogel in the root zone of plants significantly increased water use efficiency.

Table (7): Effect of some water saving substances and irrigation treatments on yield components of "Washington Navel" orange trees in 2015 and 2016 seasons.

\begin{tabular}{|c|c|c|c|c|c|c|}
\hline \multirow{2}{*}{ Treatment } & \multicolumn{2}{|c|}{ No. of fruits/tree } & \multicolumn{2}{c|}{ Yield(Kg/tree) } & \multicolumn{2}{c|}{ Yield (Ton/fed) } \\
\cline { 2 - 7 } & 2015 & 2016 & 2015 & 2016 & 2015 & 2016 \\
\hline $\mathrm{T}_{1}$ (Cont.) & $254.06 \mathrm{~b}$ & $252.76 \mathrm{~b}$ & $70.28 \mathrm{~b}$ & $70.51 \mathrm{ab}$ & $12.30 \mathrm{~b}$ & $12.34 \mathrm{ab}$ \\
\hline $\mathrm{T}_{2}$ & $252.43 \mathrm{~b}$ & $252.4 \mathrm{~b}$ & $66.03 \mathrm{bc}$ & $68.33 \mathrm{bc}$ & $11.55 \mathrm{bc}$ & $11.96 \mathrm{bc}$ \\
\hline $\mathrm{T}_{3}$ & $311.3 \mathrm{a}$ & $295.53 \mathrm{a}$ & $78.8 \mathrm{a}$ & $78.47 \mathrm{a}$ & $13.79 \mathrm{a}$ & $13.73 \mathrm{a}$ \\
\hline $\mathrm{T}_{4}$ & $252.4 \mathrm{~b}$ & $254.66 \mathrm{~b}$ & $65.85 \mathrm{bc}$ & $68.20 \mathrm{~b}$ & $11.52 \mathrm{bc}$ & $11.94 \mathrm{bc}$ \\
\hline $\mathrm{T}_{5}$ & $304.96 \mathrm{a}$ & $297.0 \mathrm{a}$ & $80.36 \mathrm{a}$ & $79.06 \mathrm{a}$ & $14.06 \mathrm{a}$ & $13.84 \mathrm{a}$ \\
\hline $\mathrm{T}_{6}$ & $223.6 \mathrm{c}$ & $222.96 \mathrm{c}$ & $61.36 \mathrm{c}$ & $62.26 \mathrm{bc}$ & $10.74 \mathrm{c}$ & $10.89 \mathrm{bc}$ \\
\hline $\mathrm{T}_{7}$ & $250.43 \mathrm{~b}$ & $246.7 \mathrm{~b}$ & $64.46 \mathrm{bc}$ & $64.7 \mathrm{bc}$ & $11.28 \mathrm{bc}$ & $11.32 \mathrm{bc}$ \\
\hline $\mathrm{T}_{8}$ & $221.56 \mathrm{c}$ & $221.8 \mathrm{c}$ & $60.76 \mathrm{c}$ & $60.66 \mathrm{c}$ & $10.63 \mathrm{c}$ & $10.61 \mathrm{c}$ \\
\hline $\mathrm{T}_{9}$ & $246.16 \mathrm{~b}$ & $244.06 \mathrm{~b}$ & $62.73 \mathrm{c}$ & $65.66 \mathrm{bc}$ & $10.97 \mathrm{c}$ & $11.49 \mathrm{bc}$ \\
\hline
\end{tabular}

$\mathrm{T}_{1}$. Control (Actual irrigation practiced in the orchard)

$\mathrm{T}_{2}$ - Moderate irrigation treatment $(75 \%$ from the control) + Hydrogel polymer at rate $50 \mathrm{~g} /$ tree.:

$\mathrm{T}_{3}$ - Moderate irrigation treatment + Hydrogel polymer at rate $100 \mathrm{~g} /$ tree.

$\mathrm{T}_{4}$ - Moderate irrigation treatment + organic plant residuesat rate $3.5 \mathrm{~kg} / \mathrm{tree}$.

$\mathrm{T}_{5}$ - Moderate irrigation treatment + organic plant residuesat rate $6.5 \mathrm{~kg} /$ tree.

$\mathrm{T}_{6}$ - Deficit irrigation treatment $(50 \%$ from the control) + Hydrogel polymer at rate $50 \mathrm{~g} / \mathrm{tree}$.

T7. Deficit irrigation treatment + Hydrogel polymer at rate $100 \mathrm{~g} /$ tree

T8- Deficit irrigation treatment + organic plant residuesat rate $3.5 \mathrm{~kg} / \mathrm{tree}$.

T9. Deficit irrigation treatment) + organic plant residuesat rate $6.5 \mathrm{~kg} /$ tree. 


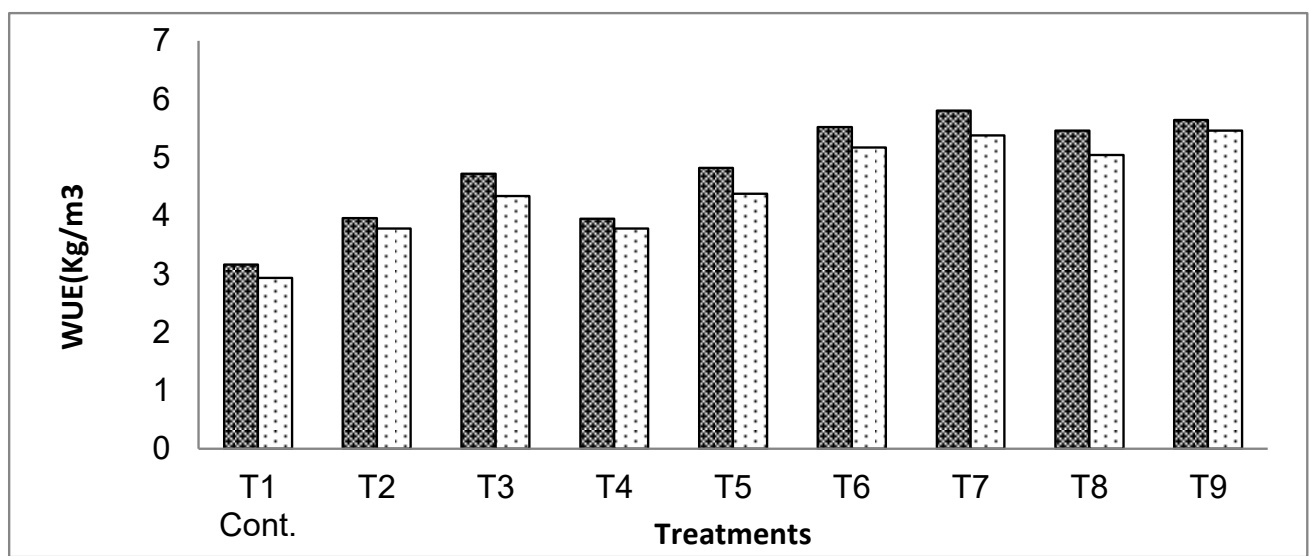

Fig. (3): Effect of some water saving substances and irrigation treatments on water use efficiency (WUE) of "Washington Navel" orange tree in 2015 and 2016 seasons.

\section{6- Fruit quality:}

About Physical fruit properties data obtained in Table (8) showed that there were no significant differences among treatments regarding to fruit weight in both seasons. The highest fruit diameter $(9.48 \mathrm{~cm})$ obtained with control $\left(T_{1}\right)$ followed by $\left(T_{8}\right)$ in the first season, but in the second season $T_{6}$ (deficit irrigation rate $+50 \mathrm{~g} /$ tree hydrogel) gave the highest value $(9.13 \mathrm{~cm})$. Both of $\left(T_{3}\right.$ and $\left.T_{4}\right)$ had significantly lower values than other treatments in both seasons. Concerning fruit height, ( $T_{3}$ and $T_{5}$ ) followed by $\left(T_{1}\right)$ tended to increase fruit diameter than the other treatments in the first season. The Highest juice weight \% was recorded with $\mathrm{T}_{5}$ compared with the lowest values obtained with $T_{8}$ in both seasons. With respect to peel thickness all treatments were significantly highest compared with the control $\left(T_{1}\right)$ without significant differences among them.

As for Chemical fruit properties the present results of fruits TSS \% in Table (9) showed that in general, there were non-significant differences among treatments in the first season, but in the second one the highest values of TSS \% were in the treatment of $\left(T_{4}, T_{6}, T_{7}\right.$ and $\left.T_{8}\right)$. Data of fruit acidity \% (Table 9 ) revealed that the studied treatments ( $T_{7}$ and $\left.T_{9}\right)$ increased the acidity of fruit juice in the first season, while $T_{8}$ and $T_{9}$ gave the highest values in this respect compared with control and other treatments in the second one. The control gave the highest TSS / acid ratio (17.06 and 15.76) compared with the other treatments in both seasons, respectively. Data of Vitamin C content in fruit juice (Table 9) showed that most of the tested treatments maintained the higher concentration of vitamin $C$ in fruit juice than the control $\left(T_{1}\right)$ during 2015 and 2016 seasons. The best treatment in this respect was $\mathrm{T}_{8}$ (Deficit irrigation rate + $3.5 \mathrm{~kg} /$ tree organic plant residues) which gave the highest level of vitamin C $(54.00$ and $53.11 \mathrm{mg}$ ) compared with the other treatments in both seasons.

From the previously mentioned results, it could be concluded that application of hydrogel gel and organic west compost enhanced fruit chemical and physical properties due to the fact that the soil was wet for a long time, microbial activity and availability of nutrient increased. These results are in line with those of Pattanaaik et al., (2015) on Khasi mandarin, Abd El-Rhman and Mohamed (2017) on olive trees. 


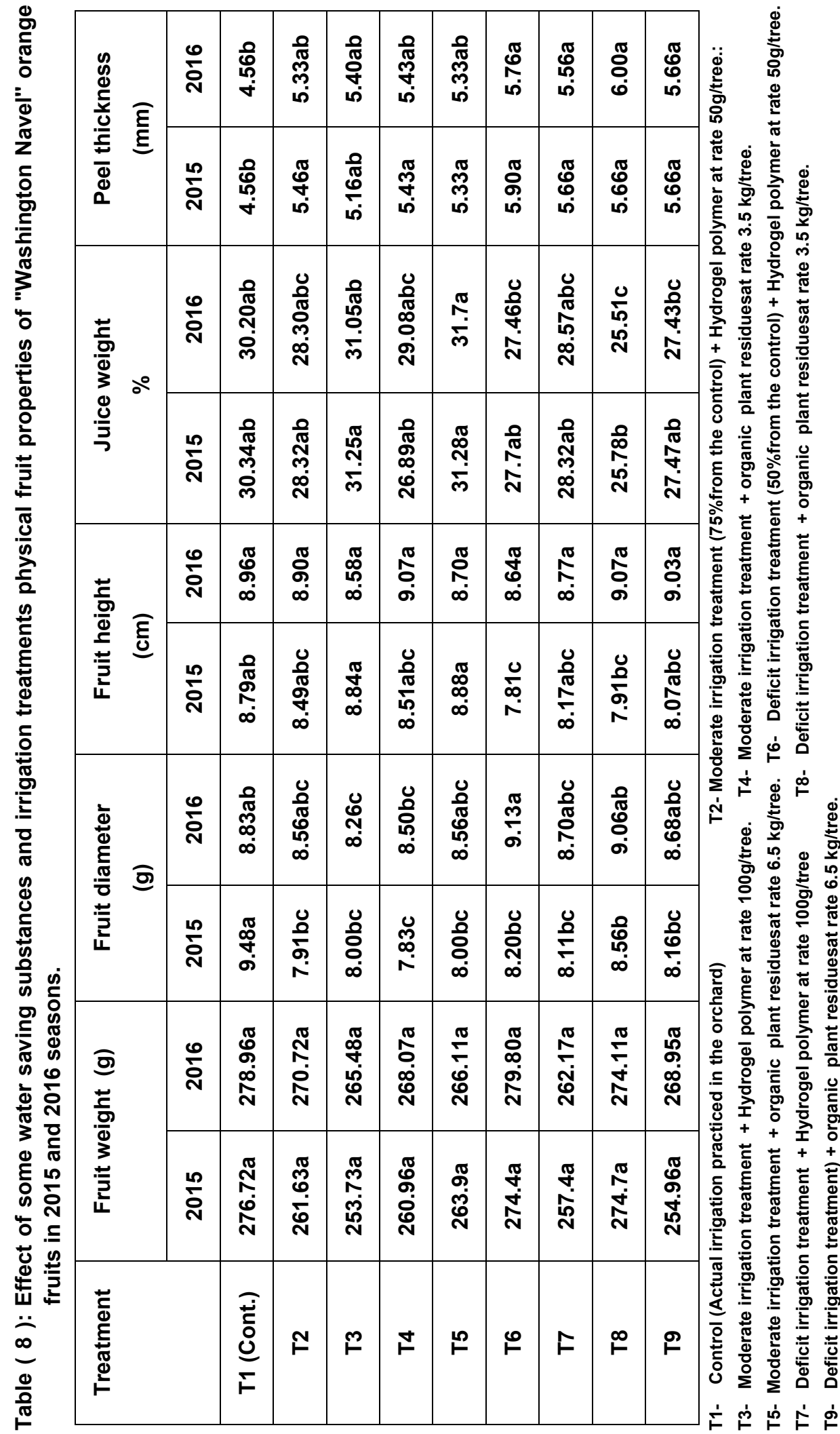


Impact of chemical and natural water saving soil amendments on growth, ..........

Table (9): Effect of some water saving substances and irrigation treatments on chemical fruit properties of "Washington Navel" orange fruits in 2015 and 2016 seasons.

\begin{tabular}{|c|c|c|c|c|c|c|c|c|}
\hline \multirow{2}{*}{ Treatment } & \multicolumn{2}{|c}{ TSS \% } & \multicolumn{2}{c|}{ Acidity \% } & \multicolumn{2}{c|}{ TSS /acid ratio } & \multicolumn{2}{c|}{$\begin{array}{c}\text { Vitamin C } \\
\text { (mg/100 ml fresh juice) }\end{array}$} \\
\cline { 2 - 8 } & 2015 & 2016 & 2015 & 2016 & 2015 & 2016 & 2015 & 2016 \\
\hline$T_{1}$ (Cont.) & $11.26 \mathrm{a}$ & $11.30 \mathrm{~b}$ & $0.66 \mathrm{c}$ & $0.71 \mathrm{e}$ & $17.06 \mathrm{a}$ & $15.76 \mathrm{a}$ & $47.53 \mathrm{bc}$ & $48.83 \mathrm{abc}$ \\
\hline $\mathrm{T}_{2}$ & $11.33 \mathrm{a}$ & $11.40 \mathrm{ab}$ & $0.94 \mathrm{~b}$ & $0.86 \mathrm{~d}$ & $12.93 \mathrm{~b}$ & $13.40 \mathrm{~b}$ & $45.86 \mathrm{bc}$ & $48.33 \mathrm{abc}$ \\
\hline $\mathrm{T}_{3}$ & $11.50 \mathrm{a}$ & $11.55 \mathrm{ab}$ & $0.93 \mathrm{~b}$ & $0.91 \mathrm{~cd}$ & $12.93 \mathrm{~b}$ & $12.6 \mathrm{bc}$ & $45.83 \mathrm{bc}$ & $47.20 \mathrm{bc}$ \\
\hline $\mathrm{T}_{4}$ & $12.03 \mathrm{a}$ & $12.16 \mathrm{a}$ & $0.93 \mathrm{~b}$ & $0.89 \mathrm{~d}$ & $13.1 \mathrm{~b}$ & $13.70 \mathrm{~b}$ & $43.73 \mathrm{c}$ & $45.23 \mathrm{c}$ \\
\hline $\mathrm{T}_{5}$ & $11.86 \mathrm{a}$ & $11.93 \mathrm{ab}$ & $0.95 \mathrm{ab}$ & $0.97 \mathrm{bcd}$ & $12.53 \mathrm{~b}$ & $12.23 \mathrm{bc}$ & $43.60 \mathrm{c}$ & $45.56 \mathrm{c}$ \\
\hline $\mathrm{T}_{6}$ & $12.33 \mathrm{a}$ & $12.36 \mathrm{a}$ & $1.08 \mathrm{ab}$ & $1.03 \mathrm{abc}$ & $11.46 \mathrm{~b}$ & $12.00 \mathrm{bc}$ & $45 \mathrm{bc}$ & $47.23 \mathrm{bc}$ \\
\hline $\mathrm{T}_{7}$ & $12.40 \mathrm{a}$ & $12.41 \mathrm{a}$ & $1.15 \mathrm{a}$ & $1.06 \mathrm{ab}$ & $10.76 \mathrm{~b}$ & $11.70 \mathrm{bc}$ & $44.96 \mathrm{bc}$ & $49.30 \mathrm{abc}$ \\
\hline $\mathrm{T}_{8}$ & $12.30 \mathrm{a}$ & $12.33 \mathrm{a}$ & $1.11 \mathrm{ab}$ & $1.11 \mathrm{a}$ & $11.13 \mathrm{~b}$ & $11.06 \mathrm{c}$ & $54.00 \mathrm{a}$ & $53.11 \mathrm{a}$ \\
\hline $\mathrm{T}_{9}$ & $12.10 \mathrm{a}$ & $12.13 \mathrm{ab}$ & $1.15 \mathrm{a}$ & $1.10 \mathrm{ab}$ & $10.53 \mathrm{~b}$ & $11.00 \mathrm{c}$ & $50.96 \mathrm{ab}$ & $51.55 \mathrm{ab}$ \\
\hline
\end{tabular}

T1. Control (Actual irrigation practiced in the orchard)

$\mathrm{T}_{2}$ - Moderate irrigation treatment $(75 \%$ from the control) + Hydrogel polymer at rate $50 \mathrm{~g} /$ tree.:

$\mathrm{T}_{3}$. Moderate irrigation treatment + Hydrogel polymer at rate $100 \mathrm{~g} /$ tree.

$\mathrm{T}_{4}$ - Moderate irrigation treatment + organic plant residuesat rate $3.5 \mathrm{~kg} / \mathrm{tree}$.

$\mathrm{T}_{5-}$ Moderate irrigation treatment + organic plant residuesat rate $6.5 \mathrm{~kg} /$ tree.

$\mathrm{T}_{6}$. Deficit irrigation treatment $(50 \%$ from the control) + Hydrogel polymer at rate $50 \mathrm{~g} /$ tree.

$\mathrm{T}_{7}$. Deficit irrigation treatment + Hydrogel polymer at rate $100 \mathrm{~g} / \mathrm{tree}$

T8- Deficit irrigation treatment + organic plant residuesat rate $3.5 \mathrm{~kg} / \mathrm{tree}$.

$T_{9}$. Deficit irrigation treatment) + organic plant residuesat rate $6.5 \mathrm{~kg} / \mathrm{tree}$.

\section{Fruit splitting \%}

Results illustrated in Fig. (4) clarry that the highest percentage of fruit splitting \% (11.11 and 10\%) and (10.06 and $9.91 \%$ ) was observed in the treatment of deficit irrigation rate +3.5 or $6.5 \mathrm{~kg} /$ tree organic plant residues $\left(T_{8}\right.$ and $T_{9}$ ), while the lowest percentage of fruit splitting (6.83 and $6.33 \%)$ and $(6.9$ and $5.14 \%)$ coated with moderate irrigation rate $+100 \mathrm{~g} /$ tree hydrogel $\left(\mathrm{T}_{3}\right)$ and 6.5 $\mathrm{kg} /$ tree organic plant residues $\left(T_{5}\right)$ in both seasons .

Generally, the fruit splitting is mostly likely to occur shortly before maturity, when rains or irrigation follow a period of drought. Chandra (1988) observed that due to sudden increase in water content of soil and atmospheric humidity after long dry spell, the tissues of fruit skin of lemon did not cope with the rapid increase of the fruit internal tissues, resulting in the bursting of the skin. GaoFeifei et al (1994) observed that water stress caused fruit cracking in citrus. Li and Hunag (1995) reported that drought conditions reduce calcium uptake and increase fruit cracking in litchi. Huang et al (2000) observed that water stress during fruit development has been linked to lower rind $\mathrm{Ca}$ levels, and in turn has 
been associated with increased incidences of albedo breakdown. From the previously mentioned results, it could be concluded that application of hydrogel and organic west compost treatments decreased fruit splitting percentage through optimization of soil moisture by increasing soil hold capacity. The same results were also obtained by $\mathrm{Abo} \mathrm{El}-$ Enin (2012), El-Zawily (2016), Zaghloul and Moursi (2017) on "Navel orange" trees, who showed that, soil must be kept fairly wet during summer months to avoid that disorders in fruits (creasing, splitting, and scald) which associated with water shortage.

\section{7- Soil properties}

Soil microorganisms content and dehydrogenase activity:

Results illustrated in Fig. (5 and 6) indicated that soil microorganisms content (Colonies number of fungi, bacteria and yeast) and dehydrogenase activity were increased under treatments of $\mathrm{T}_{4}$ and $\mathrm{T}_{5}$ (moderate irrigation rate + 3.5 or $6.5 \mathrm{~kg} /$ tree organic plant residues) followed by $T_{9}$ (deficit irrigation rate + $6.5 \mathrm{~kg} /$ tree organic plant residues) compared to the control $\left(T_{1}\right)$. This findings may be attributed to organic amendments improve the soil aeration, water infiltration, and water holding capacity, also many organic amendments contain plant nutrients that act as organic fertilizers and are also energy sources for bacteria, fungi, and earthworms that live in the soil (Davis and Wilson, 2005). However, The polymers improved the physical properties of poorly structured and influence the density, structure, compaction, texture, aggregate stability and crust hardness of the soil as well as the evaporation rates and microbial activity (John, 2011). In addition, increasing number of soil microorganisms under moderate and deficit irrigation rates, possibly due to better soil aeration. Also, soil microorganisms significantly increased during the vigorous plant growth stage. A vigorous root system should produce abundant secretion that may help the reproduction of microbes. The obtained results are in agreement with those reported by Wang et al., (2008) and ElZawily (2016) who showed that water deficit produced an increase of soil microorganism and dehydrogenase activity.

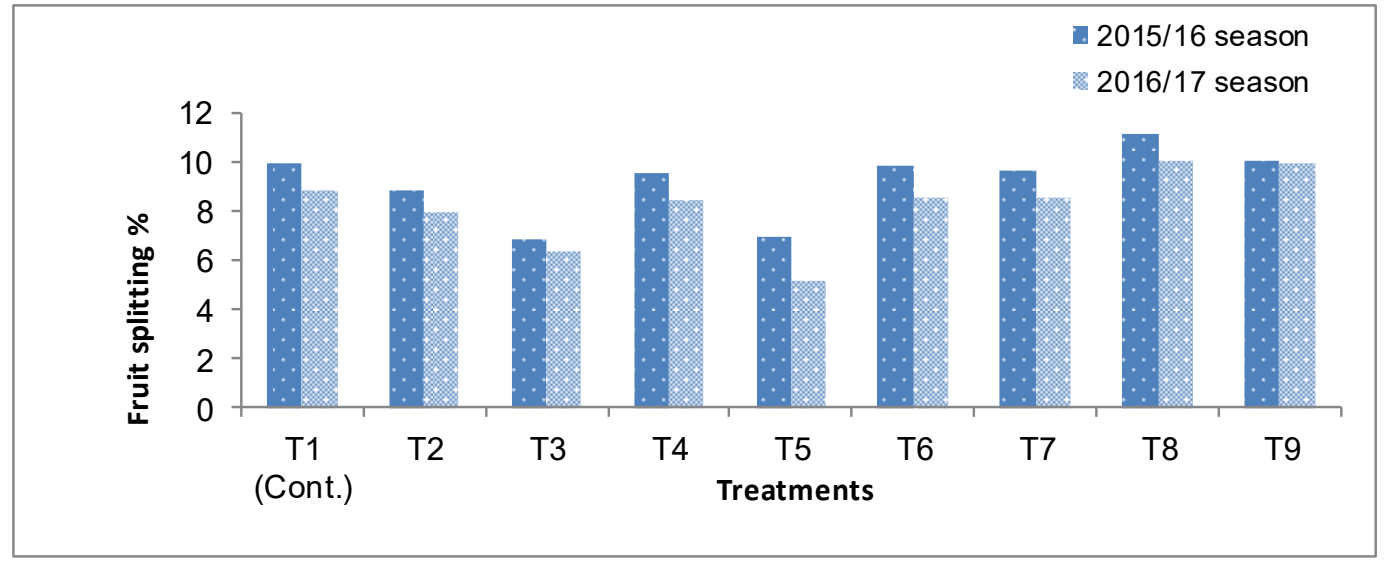

Fig. (4): Effect of some water saving substances and irrigation treatments on fruit splitting \% of "Washington Navel" orange fruits in 2015 and 2016 seasons. 


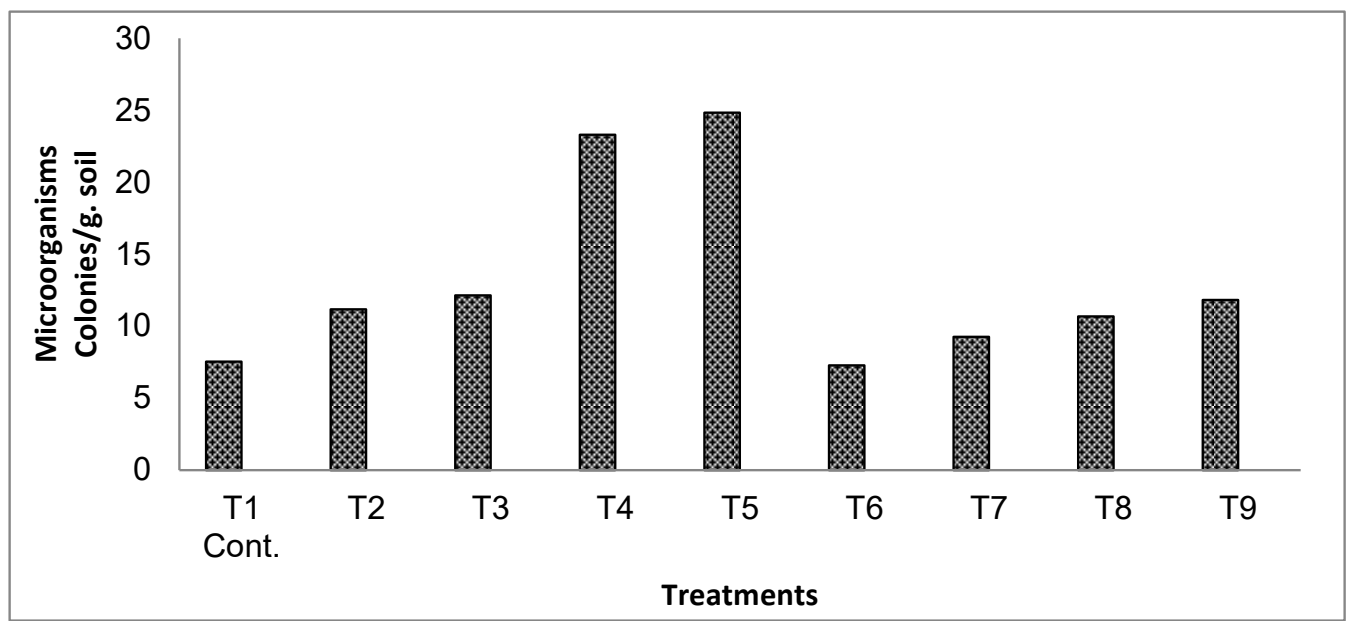

Fig. (5): Effect of some water saving substances and irrigation treatments on soil microorganisms content as number of colonies/g soil in 2016 season.

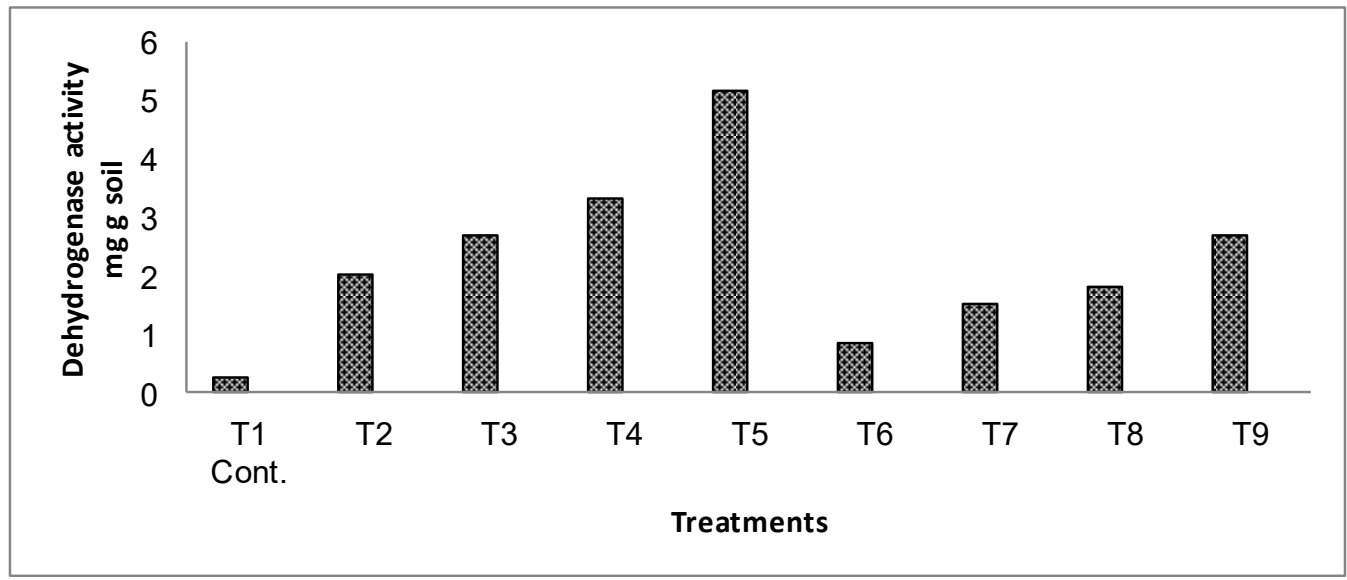

Fig. (6): Effect of some water saving substances and irrigation treatments on dehydrogenase activity ( $\mathrm{mg} \mathrm{g}^{-1}$ dry soil/96h) in 2016 season.

\section{CONCLUSION}

Based on the results obtained from this study, it is recommended to add $100 \mathrm{~g} /$ tree hydrogel polymer or $6.5 \mathrm{~kg} /$ tree organic plant residues of "Washington Navel" orange trees under moderate irrigation $(75 \%$ actual irrigation practiced in the orchard) which considered the best treatment in the ability to improve the growth attributes, yield, fruit quality characters and rationalize about $25 \%$ of the amount of irrigation water/fed./year in sandy soil under the experimental conditions.

\section{REFERENCES}

A.O.A.C. (1995). Association of official analytical chemists. Official Methods of Analysis. $15^{\text {th }}$ Ed. Washington D.C., USA.

Abd El-Rhman, I. E. and S. A. Mohamed (2017). Enhancing olive trees growth and productivity by using hydrogel and potassium humate under rain-fed condition in Northern Western Coastal zone. Egyptian J. Desert Res., 67 (1): 137-151.

Abo El-Enin, M.M.S. (2012). Improvement of "Washington Navel" orange fruit 
quality using water regimes and GA3, potassium and calcium foliar applications. Ph.D. Thesis, Fac. Agric., Kafrelsheikh Univ., Egypt.

Ali, M. H., M.R. Hoque, A. A. Hassan and A. Khair (2007). Effects of deficit irrigation on yield, water productivity and economic returns of Wheat. Agricultural water management, 92(3) : 151-161.

Andry, H., T. Yamamoto, T. Irie, S. Moritani, M. Inoue and $\mathrm{H}$. Fujiyama (2009). Water retention, hydraulic conductivity of hydrophilic polymers in sandy soil as affected by temperature and water quality. Journal of Hydrology 373: 177-183.

Arbona, V., D. J. Iglesias, J. Jacas, E. Primo-Millo, M. Talon and A. Cadenas (2015). Hydrogel substrate amendment alleviates drought effects on young citrus plants. Plant and Soil, 270: 7382.

Barki, N., H. Chehab, F. Aissaoui, 0. Dabbaghi, F. Attia, Z. Mahjoub, S. Laamari, B. Chihaoui, T. Giudice, A. Jemai, D. Boujnah and B. Mechri (2018). Effects of mycorrhizal fungi inoculation and soil amendments with hydrogel on leaf anatomy, growth and physiology performance of olive plantlets under two contrasting water regime. Acta Physiologiae Plantarum 40, 116-126.

Bricker, B. (1991). MSTATC: A micro computer program from the design management and analysis of agronomic research experiments. Michigan State

Buchholz, F.L. and A.T. Graham (1998). In "modern superabsorbent polymer technology", Wiley, V.C.H. (ed.), New York, NY (USA). ISBN: 0-471-19411-5.

Castle, W. (1983). Growth, yield and cold hardiness of seven year old 'Bearss' lemon on twenty seven rootstocks. Proc. Florida Sta. Hort. Soc. 96: 23-25.
Chandra, M. (1988). Studies on fruit cracking in lemon (Citrus limon). M.Sc. Thesis , G.B. Pant University of Agriculture and Technology, Pantnagar. Univ., USA.

Chapman, H.D. and P.F. Pratt (1978). Methods of analysis for soils, plant and water. Univ. California USA.

Chehab, H., M. Jemaic, M. Guiaaa, Z. Mahjouba, D. Boujnaha, S. Laamaria, B. Chihaouia, H. Zakhamad, M. Hammamib and T. Giudiceea (2017). Effect of the super absorbent polymer stockosorb $\AA$ on leaf turgor pressure, tree performance and oil quality of olive trees cv. Chemlali grown under field conditions in an arid region of Tunisia. Agricultural Water Management 192: 221-231.

Chou, G.J. (1966). A new method of measuring the leaf area of citrus trees. Acta. Hort. Sin., 5: 17-20.

Davis, J.G and C.R. Wilson (2005). Choosing a soil amendment. Colorado State University Cooperative Extension Horticulture.7: 235.

Duncan, B.D. (1955). Multiple range and multiple F-test . Biometrics, J. 11:1-42.

El-Shafei, Y.Z., A.M., Al-Omran, A.M. AlDarby and A. A. Shalaby (1992) Influence of upper layer treatment of gel-conditioner on water movement in sandy soils under sprinkler infiltration. Arid Soil Research and Rehabilitation 6: 217-231.

El-Zawily, H. (2016). Evaluation the Effect of Different Kinds of Fertilizers on Soil Properties, Vegetative Growth, Yield and Fruit Quality of "Washington Navel" Orange Trees Under Different Irrigation Levels in Sandy Soil. Ph.D. Thesis, Fac. Agric., Kafrelsheikh Univ., Egypt.

Eneji, A.E., R. Islam, P. An and U.C. Amalu (2013). Nitrate retention and physiological adjustment of maize to soil amendment with superabsorbent 
polymers. Journal of Cleaner Production 52:474-480.

Ezzat, A. S., A. A. El-Awady and H. M. I. Ahmed (2011). Improving nitrogen utilization efficiency by potato (Solanum tuberosum L.). Effect of irrigation intervals, nitrogen rates and hydrogel on growth, yield, quality and nutrient uptake. Nature and Sci., 9(7): 34-41.

Fagundes, M., C. Pereira, S. Camilo, R. A. Moreira and M. Cruz (2014). Hydrogel polymer in emergency and early growth of citrus rootstocks. Afr. J. Agric. Res. 9(35):2681-2686.

FAO (2016). Food and agriculture organization of the UN regional office for Africa, ACCRH. RAF Publication, 2016/01.

Fernando, T.N., A.G.B. Aruggo, C. K. Disanayaka and S. Kulathunge (2013). Effect of super water absorbent polymer and watering capacity on growth of tomato (Lycopersicon esculentum Mill) Journal of Engineering and Technology of the Open university of Sri Lanka (JETOUSL), 1(2):1-14.

Gao-Feifei, H., H. Uıbai and X. Jiankat (1994). An investigation on the cause of fruit-crack in "Hangijung" orange. J South China Agric 15:34-39.

Huang, X. M., H. B. Huang and F. F. Gao (2000). The growth potential generated in citrus fruit under water stress and its relevant mechanisms. Scientia Hort 83:227-240.

Jackson, M.L. (1967). Soil chemical and analysis. Prentice Hall of India, New Delhi.

Jamnicka, G., L.D. Ditmarova, J. Kurjak, E. Kmet, M. Psidova, D. Mackova and K. Gomory (2013). The soil hydrogel improved photosynthetic performance of beech seedlings treated under drought. Plant Soil Environ., 59 (10): 446-451.
John, G.F. (2011). Towards improved application of super absorbent polymers in agriculture and hydrology: A cross-disciplinary approach. Master thesis of science. Graduate Faculty of Auburn University, Alabama.

Khoshnevis, N. (2003). Application of the superabsorbent hydrogel for suitable irrigation in landscape and cultured frosts around sites. Proceedings of the $2^{\text {nd }}$ Educational Course for Agricultural and Industrial Application of Superabsorbent Hydrogels. Tehran, Iran.

Lentz, R.D., I. Shainberg, R. E. Sojka and D.L. Carter (1992). Preventing irrigation furrow erosion with small applications of polymers. Soil Sci. Soc. Am. J. 56:1926-1932.

Li, J. G., and H. B. Huang (1995). Physicochemical properties and peel morphology in relation to fruitcracking susceptibility in litchi fruit. $\mathbf{J}$ South China Agric Uni 16:84-89.

Lou, Y.L., M. G. Xu., W. Wang, X.L. Sun and $K$. Zhao (2011). Return rate of straw residue affects soil organic $\mathrm{C}$ sequestration by chemical fertilization. Soil and Tillage Research. 113, 70-73.

Moldes, A., Y. Cendón and M. T. Barral (2007). Evaluation of municipal solid waste compost as a plant growing media component, by applying mixture design. Bioresource Tech .98(16): 3069-3075.

Morgan, J. M. (1984). Osmoregulation and water stress in higher plants. Annual Revision of Plant Physiology 35: 299319.

Murphy, J. and J.D. Riely (1962). A modified single solution method for the determination of phosphate in natural water. Anal. Chem. Acta, 27: 31-36.

Panayiotis, A., K. Nektarios, A.E. Nikolopoulou and I. Chronopulos (2004). Sod establishment and turf 
grass growth as affected by ureaformaldehyde resin foam soil amendment. Sci. Hort., 100: 203-213.

Pattanaaik, S. K., L. Wangchu, B. Singh, B. N. Hazarika, S. M. Singh and A. K. Pandey (2015). Effect of hydrogel on water and nutrient management of Citrus reticulate. Res. on Crops 16 (1) : 98-103.

Saleh, M.M. (2002). Biological control of some soil disease on Corn. M.Sc. Fac. Agric. Kafr El-sheikh. Tanta University, PP 27.

Sheikh, F., A. Arji, A. Esmaeeli and A. Abdousi (2010). Study of the effect of irrigation interval and superabsorbent polymer on some qualitative properties of sports turf. J. Hort. Sci., 25(2): 170-177

Snedecor, G.W. and W.G. Cochran (1990). Statistical methods. 7th Ed. Iowa State Univ. Press. Ames., lowa, USA, p. 593.

Tabatabai, M.A. (1982). Soil enzymes, Dehydrogenases. In: Methods of Soil Analysis. Part 2. Chemical and Microbiolgical Properties (Eds R.H. Miller and D.R. Keeney). Agron. Monography, 9, ASA and SSSA, Madison, WI.

Todorov, D., V. Alexieva and E. Karanov (1998). Effect of putrescine, 4-PU30, and abscisic acid on maize plants grown under normal, drought, and rewatering conditions. Plant Growth Regulator. 17:197-203.

Tongo, A., M. Ali and S. Ehsan (2014). Effect of superabsorbent polymer aquasorb on chlorophyll, antioxidant enzymes and some growth characteristics of Acacia victoriae seedlings under drought Stress. Ecopersia, 2 (2).

Uckoo, R.M., J.M. Enciso, I. Wesselman and S.D. Nelson (2009). Impact of compost application in citrus production under drip and micro jet spray irrigation system. Tree and Forestry Science and Biotechnology(Special Isssue1):59-65.

Vichiato, M., M. Medeiros and C. Ramirez (2004). Growth and mineral composition of the Cleópatra mandarin rootstock growing on substratum added with hidroretentive polymers. Ciênc. agrotec., Lavras, 28, ( 4):748-756.

Wang, J., S. Kang, F. Li, F. Zhange, Z. Li and J. Zhang (2008). Effects of alternate partial root-zone irrigation on soil microorganism and maize growth. Plant Soil, 302: 45-52.

Yazdani, F., I. Allahdadi and G.A. Akbari (2007). Impact of superabsorbent polymer on yield and growth analysis of soybean (Glycine max L.) under drought stress condition. Pakistan J. of Biolog. Sci., 10 (23): 4190-4196.

Zaghloul, A. E. and E. A. Moursi (2107). Effect of irrigation scheduling under some bio-stimulants foliar application for navel orange trees on some water relations, productivity, fruit quality and storability in the North Nile Delta Region. Alexandria Science Exchange Journal, 38 (4):671-682. 
تأثير محسنات التربة الكيماوية والطبيعية الموفرة للمياه على النمو و المحصول و كفاءة استخدام المياه لأثجار البرتقال ابوسرة تحت ظروف نقص الرى

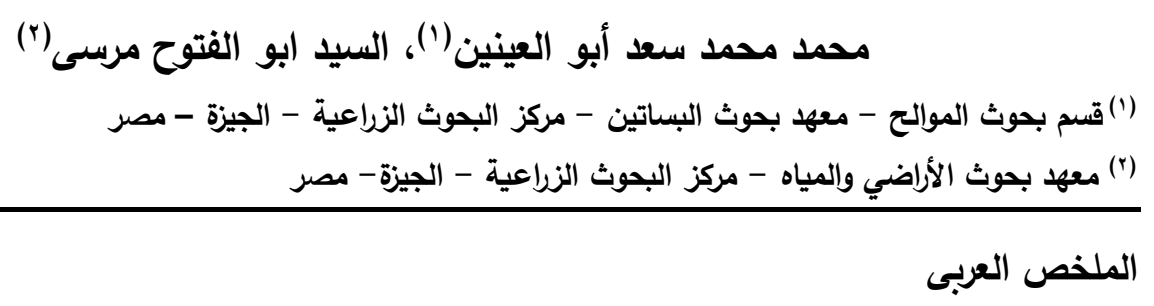

نظرًا لمدودية موارد المياه ، فقد أصبح من الضروري دراسة أفضل الطرق لتقليل استخدام مياه الري ، وزيادة كفاءة

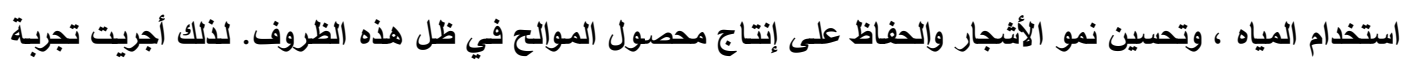

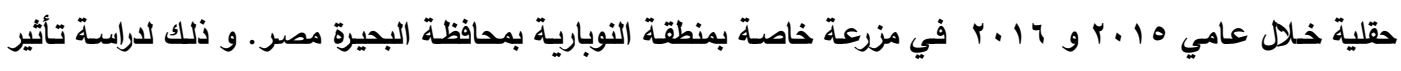

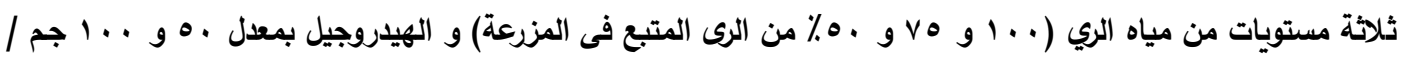

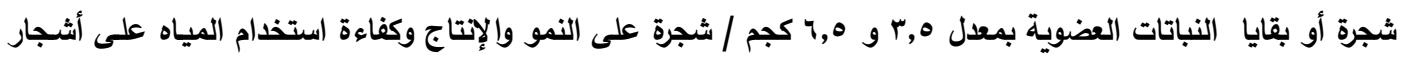

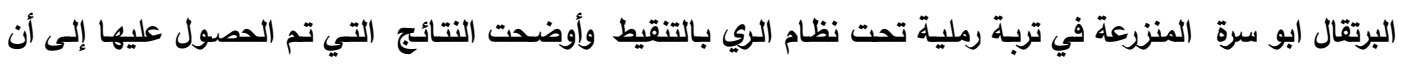

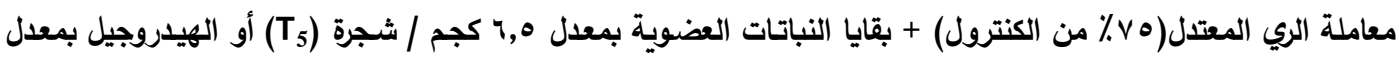

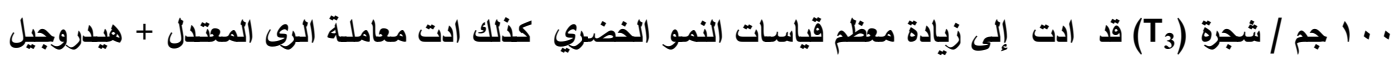

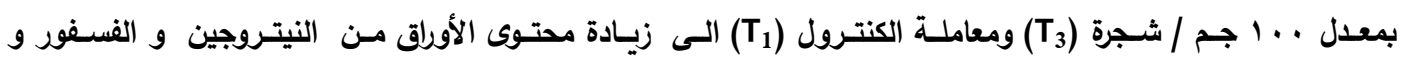
البوتاسيوم و الكالسيوم

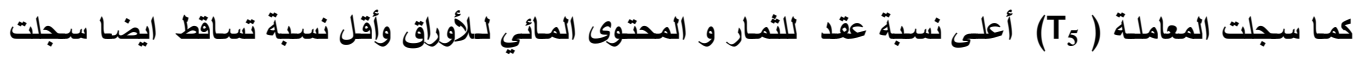

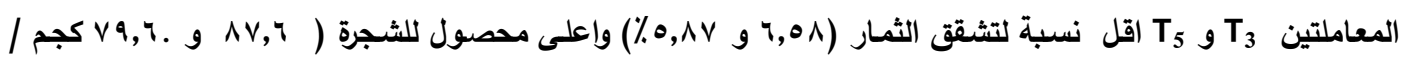

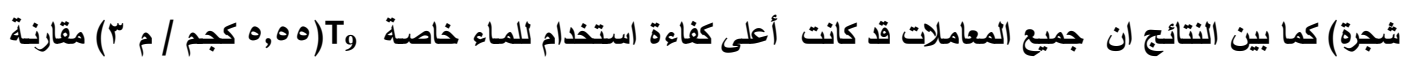

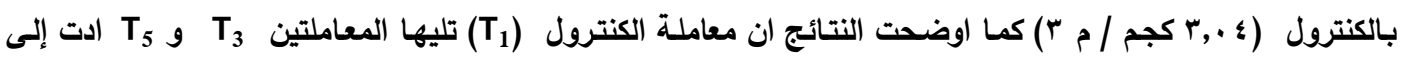

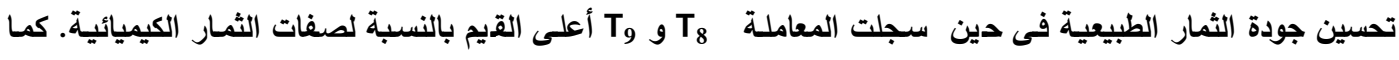

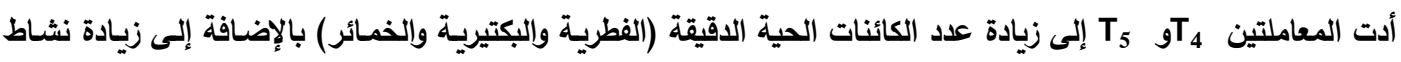

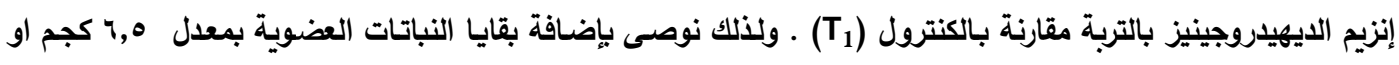

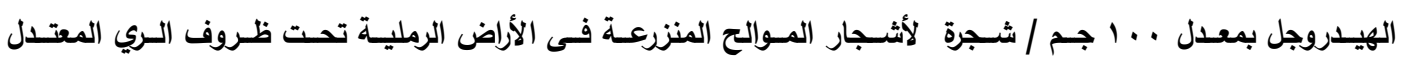

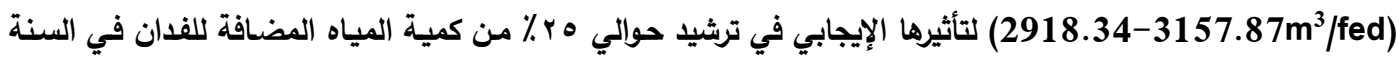
بدون أي تأثيرات سلبية على النمو الخضري والمحصول وصفات جودة الثمار.

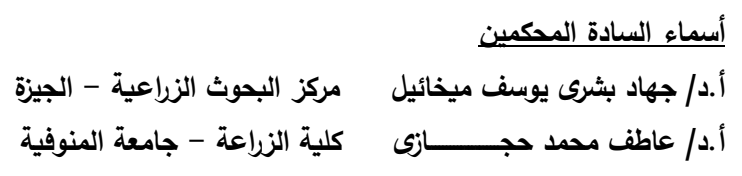

